\title{
UTILIZING COMPOST AND BIOCHAR IN ENHANCING PHYTOREMEDIATION OF CONTAMINATED SOIL
}

\author{
E.A. Abou Hussien, M.H. Shalaby and B. S.O. Alshahri \\ Soil Sci. Dept., Fac. Agric. Menoufia univ.
}

Received: Oct. 26,2020

Accepted: Nov. 4, 2020

ABSTRACT: A pot experiment was carried out at a private farm to evaluate the effective roll of the organic amendments (compost and biochar) as well as the plant cultivated (sugar beet) Beta Vulgaris L. on partial removing of heavy metals from the contaminated soil at Berkat EL-Saba region of Menoufia Governorate, Egypt. Compost and biochar were added into the soil at rates of $0,0.5,1.0$ and $2.0 \%$. A completed randomized block design with three replicates was applied. Soil EC ( $\left.\mathrm{dSm}^{-1}\right)$, CEC (cmole $\mathrm{Kg}^{-1}$ ), OM (\%) and available $\mathrm{Fe}, \mathrm{Mn} \mathrm{Zn}, \mathrm{Cu}, \mathrm{Co}, \mathrm{Cd}, \mathrm{Ni}$ and $\mathrm{Pb}\left(\mathrm{mgkg}^{-1}\right)$ were augmented with application of compost and biochar. Soil $\mathrm{pH}$ was slightly raised with biochar however, it reduced with compost addition. A significant enhancement in the fresh and dry weights of sugar beet plant and its content from the determined heavy metals obviously observed with the two amendments applied. The high uptake from determined heavy metals by sugar beet plants may attract the attention to the importance of this plant in remediating the contaminated soil with heavy metals.

Key words: Pollution, Heavy metals, Compost, Biochar, Sugar beet, Nutrients uptake and Soil properties

\section{INTRODUCTION}

Middle Delta region of Egypt (Menoufia Governorate) have many resources of pollution such as industrial activity and high way products either from atmospheric emissions or through discharge points of drainage water. Heavy metals contamination of soil in this region is typically quantified and regulated on the basis of total content, regardless of solubility. Nile Delta soils containing much colloidal organic and mineral materials can sorbs and immobilize these metals to a greater extent than soils poor in these reactive materials (Tantawy, 2004 and Basiouny, 2016).

The heavy metals are the most hazards of inorganic contaminants. Although many of heavy metals are needed in small quantities by plants and animals, they may enter soils in great enough quantities to pose risks to plants, animals and humans health. Heavy metals have been known to adversely affect soil physical and chemical properties, plant growth, and soil microbial organisms (Gibbs et al., 2006).

Soil organic matter is considered as a major component of soil quality because it contributes directly or indirectly to many physical, chemical and biological properties. Thus, soil amendment with composts is an agricultural practice commonly used to improve soil quality and also to manage organic wastes (Perez-Piqueres et al., 2006).

Soil amendment is a major requirement for the successful establishment of vegetation in metalcontaminated soils. The addition of amendments into soils precipitates or increases metal sorption, therefore decreasing the proportion of the total element in soil solution (de Varennes et al., 2006). The addition of amendments such as compost and humic substances are effective in lowering the metal toxicity 
of soil and provides a slow release of nutrient sources (Faiyad, 2014 and Chen et al., 2015).

Biochar is the solid product material produced during a process known as pyrolysis from the thermo-conversion of biomass under little or no oxygen for use in soils as an amendment (Gaskin et al., 2008 and Lehmann and Joseph, 2009). During pyrolysis, labile carbon (C) is converted into a relatively stable aromatized C (Krull et al., 2012), while basic cations are transferred from the fresh biomass to biochar. This is advantageous because when biochar is applied to the soil, these basic cations become available to the soil by occupying the soil exchange sites (Wang et al., 2009). Biochar considered one of pyrolysis products in addition to biofuel and syngas. Biochar can persist in soils and sediments for many centuries (Glaser, 2007 and Downie et al., 2012) and has great potential to improve agronomic production when applied as a soil amendment (Laird et al., 2009). Potentially leading to a significant reduction in atmospheric greenhouse gas (GHG) levels. Thus, biochar may offer a win-win technology to mitigate global warming and food security (Lehmann, 2007b).

The role of organic materials and their metabolites in limiting the hazardous action of soil pollution depends on a number of factors i.e. type and contents of each of organic materials (as chelating agents) and heavy metals, soil conditions (mainly $\mathrm{pH}, \mathrm{CaCO}_{3}$ and texture), growing plants and agronomic practices (Walker et al., 2003 and El- Gamal, 2015).

This work was carried out to study the effect of two soil organic amendments at different application rates on status of some heavy metals and some chemical properties as well as stimulating the growth of sugar beet plant as a phytoremediater plant for the contaminated soil.

\section{MATERIALS AND METHODS}

The tested soil was brought from Berket El-Saba region of Menoufia Governorate South-West Nile Delta, Egypt which affected by the pollution of highway product sources (CairoAlexandria Agricultural Road). Six, surface $(0-20 \mathrm{~cm})$ soil samples were brought from different sites, air-dried, ground, well mixed, and sieved through a $2 \mathrm{~mm}$ sieve. A portion of fine soil $(<2 \mathrm{~mm})$ sample was taken and analyzed for its physical and chemical properties and also for its content of biogenic ( $\mathrm{Fe}, \mathrm{Mn}$, $\mathrm{Zn}$, and $\mathrm{Cu}$ ) and non-biogenic ( $\mathrm{Co}, \mathrm{Cd}, \mathrm{Ni}$ and $\mathrm{Pb}$ ) heavy metals according to the methods described by Klute and Dirksen (1986) and Page et al. (1982). The obtained data of these determinations were recorded in Table (1). The other remained fine soil was kept to use in the greenhouse experiment.

Two soil organic amendments varied in their chemical properties were used in this study. These amendments were compost produced from mixture of rice straw (RS) and cattle manures (CM) at a ratio of 1:1 by dry weight and biochar produced from maize stalk (MS). The fine biochar and compost were analyzed for some physical and chemical properties using the methods described by Klute and Dirksen (1986) and Page et al. (1982) and the obtained data were recorded in Table (1).

Sugar beet (Beta Vulgaris L.) seeds were brought from Sugar Crops Research Institute, Agricultural Research Center "ARC", Egypt. A greenhouse pot experiment was conducted during the summer season of 2018. 24 plastic pots with $25 \mathrm{~cm}$ diameter and $30 \mathrm{~cm}$ depth were used in this experiment. Each pot was filled with $5 \mathrm{~kg}$ of fine soil. These pots were divided into two main groups 
(12 pot/ main group) representing the used soil amendments (compost and biochar). All pots received calcium super phosphate $\left(15.5 \% \mathrm{P}_{2} \mathrm{O}_{5}\right)$ at a rate of 300 $\mathrm{kg} \mathrm{fed}^{-1}\left(1.5 \mathrm{~g} \mathrm{pot}^{-1}\right)$ before planting and well mixed with the potted soil.

The pots of each main group were divided into four subgroups (3pot/sub subgroup) represent the application rates of compost and biochar $0,0.5,1.0$ and $2.0 \%(0,2.5,5$ and $10 \mathrm{~g} /$ pot $\mathrm{w} / \mathrm{w})$. The treatments were arranged in a completely randomized block design with three replicates. Organic amendments were added before planting and well mixed with the potted soil. Then each pot was planted by two seeds of sugar beet (Beta Vulgaris L, CV, 24) at first day of May 2018 and irrigated by tap water at $60 \%$ of water holding capacity (W.H.C) of each treatment.

Table (1): Some physical and chemical properties of the used compost and biochar and their content $\left(\mathrm{mg} \mathrm{kg}^{-1}\right)$ of some determined heavy metals

\begin{tabular}{|c|c|c|}
\hline \multirow{2}{*}{ Properties and units } & \multicolumn{2}{|c|}{ Organic amendments (OA) } \\
\hline & Compost & Biochar \\
\hline Bulk density $\left(\mathrm{g} / \mathrm{cm}^{3}\right)$ & 0.82 & 0.45 \\
\hline $\mathrm{pH}, 1: 2.5$ water suspension & 7.50 & 8.15 \\
\hline$E C, 1: 5$ water extract $\left(\mathrm{dSm}^{-1}\right)$ & 2.11 & 4.75 \\
\hline CEC (C. mole $\mathrm{kg}^{-1}$ ) & 125.81 & 38.45 \\
\hline Organic carbon "OC" (\%). & 23.50 & 47.75 \\
\hline Total nitrogen "N" (\%). & 1.10 & 0.86 \\
\hline $\mathrm{C} / \mathrm{N}$ ratio & 21.37 & 55.52 \\
\hline \multicolumn{3}{|l|}{ Total macronutrients $\left(\mathrm{gkg}^{-1}\right)$} \\
\hline $\mathbf{N}$ & 11.00 & 3.12 \\
\hline $\mathbf{P}$ & 6.56 & 2.81 \\
\hline $\mathbf{K}$ & 90.15 & 30.28 \\
\hline \multicolumn{3}{|c|}{$\begin{array}{l}\text { Content }\left(\mathrm{mg} \mathrm{kg}^{-1}\right) \text { of some biogenic and non-biogenic heavy metals in the used } \\
\text { compost and biochar }\end{array}$} \\
\hline \multirow[t]{2}{*}{ Biogenic (HM) } & & \\
\hline & 352 & 365 \\
\hline \multirow[t]{2}{*}{$\mathrm{Fe}$} & 390 & 570 \\
\hline & 50 & 72 \\
\hline Mn & 42 & 55 \\
\hline \multirow[t]{2}{*}{$\mathrm{Zn}$} & 28 & 42 \\
\hline & 35 & 50 \\
\hline \multirow[t]{2}{*}{$\mathrm{Cu}$} & 210 & 90 \\
\hline & 18 & 25 \\
\hline Non-biogenic (HM) & & \\
\hline Co & & \\
\hline Cd & & \\
\hline $\mathrm{Ni}$ & & \\
\hline $\mathbf{P b}$ & & \\
\hline
\end{tabular}


Irrigation water was added every 5-7 days to stand the moisture content at $60 \% \mathrm{w} / \mathrm{d}$. After complete sowing (13 days) the plants of each pot were thinned to one plant. All pots were received nitrogen (N) as ammonium nitrate $(33.5 \% \mathrm{~N})$ and potassium $(\mathrm{K})$ as potassium sulphate (48$50 \% \mathrm{~K}_{2} \mathrm{O}$ ) at rates of 200 and $250 \mathrm{~kg} \mathrm{fed}^{-1}$ (1.0 and $1.25 \mathrm{~g} \mathrm{pot}^{-1}$ ), respectively. Both $\mathrm{N}$ and $K$ fertilizers were applied with irrigation water on two equal doses after 20 and 40 days of planting. At maturity stage (120 days), the plant of each pot was harvested separately as a whole, washed with tap water several times to remove any soil particles on the roots and then washed two times with distilled water. The harvested plant of each pot was divided to shoots and roots, and weighed to obtain the fresh weight (g/pot or g/plant) of both shoots and roots. Then those plant materials were air-dried and oven-dried at $70^{\circ} \mathrm{C}$ for 48 hours to obtain their dry matter yield as g/pot or g/plant. The oven-dried plants were ground and kept for chemical determination of its heavy metals content of $\mathrm{Fe}, \mathrm{Mn}, \mathrm{Zn}, \mathrm{Cu}, \mathrm{Co}, \mathrm{Cd}, \mathrm{Ni}$, and $\mathrm{Pb}$ according to Cottenie et al. (1982).

After plant harvesting, the soil of each pot well mixed, ground, sieved through a $2 \mathrm{~mm}$ sieve and analyzed for its chemical properties. i.e. soil pH, EC, CEC and the content of $\mathrm{OM}, \mathrm{CaCO}_{3}$ as well as the content of total and available $\mathrm{Fe}, \mathrm{Mn}, \mathrm{Zn}$, $\mathrm{Cu}, \mathrm{Co}, \mathrm{Cd}, \mathrm{Ni}$ and $\mathrm{Pb}$ as described by Cottenie et al. (1982) and Page et al. (1982).

The obtained data were statistically analyzed according to the computer program costat statistical software. Mean values were compared with each other using the least significant deference L.S.D. (CoStat, V. 2005).

\section{RESULTS AND DISCUSSION}

\section{Soil chemical properties}

Data in Table (2) show that, soil EC $\left(\mathrm{dSm}^{-1}\right)$ was increased significantly as a result of compost and biochar applications where those increases were higher at application rate of $2 \%$. These increases may be due to the effect of added organic amendments on the solubilization of some soil compounds. At the same application rate, the effect of compost surpassed that one of biochar application that may be related to the stable grade of added compost as well as the chemical composition and its decomposition products. Similar results were pointed out by Abd El-Aal et al. (2018) and Helmi (2018). The RC values obviously showed the positive effective influence of both compost and biochar on soil EC (Table, 2).

Soil $\mathrm{pH}$ recorded in Table (2) reveal that compost applications significantly decreased soil $\mathrm{pH}$, however a slight increasing soil $\mathrm{pH}$ were occurred with biochar applications. These findings may be cleared from RC (\%) values of soil pH (Table, 2) which were negative with compost applications and were positive with biochar treatments. These may be attributed to the chemical composition of added organic amendments and their decomposition products as well as its effect on soil properties. Abou Hussien et al. (2019) found a wide variation in soil $\mathrm{pH}$ treated with composts derived from different plant residues.

Data in Table (2) imply also a significant decline in the soil content (\%) of $\mathrm{CaCO}_{3}$ as affected by organic amendments applications, where this content was decreased from $1.73 \%$ in the un amended soil to 1.60 and $1.71 \%$ with RC values of -7.51 and $-2.88 \%$ in the soil received $2 \%$ compost and biochar, respectively. These results appear the effect of added compost on reducing the soil content of $\mathrm{CaCO}_{3}$ compared to that one of biochar application. These results are in consonance with Rabie (2019) who found similar decrease effect of $\mathrm{CaCO}_{3}$ by compost and biochar applications. 
Table (2): Some chemical properties of the used soil as affected by different application rates of two soils organic amendments (OA).

\begin{tabular}{|c|c|c|c|c|c|c|c|c|c|c|c|}
\hline \multirow{3}{*}{$\begin{array}{l}\text { Added } \\
\text { OA (a) }\end{array}$} & \multirow{3}{*}{$\begin{array}{l}\text { Added } \\
\text { rate } \\
\text { (\%) (b) }\end{array}$} & \multicolumn{10}{|c|}{ Soil Properties } \\
\hline & & \multicolumn{2}{|c|}{ EC } & \multicolumn{2}{|c|}{$\mathrm{pH}$} & \multicolumn{2}{|c|}{$\mathrm{CaCO}_{3}$} & \multicolumn{2}{|c|}{ OM } & \multicolumn{2}{|c|}{ CEC } \\
\hline & & $\mathrm{dSm}^{-1}$ & RC\% & - & RC\% & $\%$ & RC\% & $\%$ & RC\% & $\begin{array}{c}\text { cmole } \\
/ \mathbf{k g}\end{array}$ & RC\% \\
\hline Control & 0 & 0.60 & - & 7.28 & & 1.73 & & 0.80 & & 41.04 & \\
\hline Compost & $\begin{array}{c}0.5 \\
1.0 \\
2.0 \\
\text { Mean }\end{array}$ & $\begin{array}{l}0.61 \\
0.65 \\
0.70 \\
0.65\end{array}$ & $\begin{array}{c}1.67 \\
8.33 \\
16.67\end{array}$ & $\begin{array}{l}7.25 \\
7.18 \\
7.02 \\
7.14\end{array}$ & $\begin{array}{l}-0.41 \\
-1.37 \\
-3.57\end{array}$ & $\begin{array}{l}1.73 \\
1.70 \\
1.60 \\
1.68\end{array}$ & $\begin{array}{l}0.00 \\
1.73- \\
7.51-\end{array}$ & $\begin{array}{l}0.80 \\
0.87 \\
1.02 \\
0.90\end{array}$ & $\begin{array}{l}0.00 \\
2.15 \\
27.5\end{array}$ & $\begin{array}{l}41.80 \\
42.50 \\
43.42 \\
42.57\end{array}$ & $\begin{array}{l}1.85 \\
3.56 \\
5.80\end{array}$ \\
\hline Biochar & $\begin{array}{c}0.5 \\
1.0 \\
2.0 \\
\text { Mean }\end{array}$ & $\begin{array}{l}0.60 \\
0.62 \\
0.65 \\
0.62\end{array}$ & $\begin{array}{c}0 \\
3.33 \\
8.33\end{array}$ & $\begin{array}{l}7.30 \\
7.39 \\
7.50 \\
7.40\end{array}$ & $\begin{array}{l}0.27 \\
1.51 \\
3.02\end{array}$ & $\begin{array}{l}1.73 \\
1.75 \\
1.71 \\
1.73\end{array}$ & $\begin{array}{r}0.00 \\
1.16 \\
-2.28\end{array}$ & $\begin{array}{l}0.80 \\
0.84 \\
0.93 \\
0.86\end{array}$ & $\begin{array}{c}0.00 \\
5.00 \\
16.25\end{array}$ & $\begin{array}{l}41.62 \\
41.59 \\
42.15 \\
41.79\end{array}$ & $\begin{array}{l}1.41 \\
1.34 \\
2.70\end{array}$ \\
\hline L.S.D at 0 & $\begin{array}{l}\mathbf{a} \\
\mathbf{b} \\
\mathbf{a}^{*} \mathbf{b}\end{array}$ & $\begin{array}{l}0.0066 \\
0.0080 \\
0.0104\end{array}$ & & $\begin{array}{c}0.074 \\
0.0915 \\
0.1179\end{array}$ & & $\begin{array}{l}0.0175 \\
0.0214 \\
0.0276\end{array}$ & & $\begin{array}{l}0.0090 \\
0.0111 \\
0.0142\end{array}$ & & $\begin{array}{l}0.4333 \\
0.5307 \\
0.6839\end{array}$ & \\
\hline
\end{tabular}

$\mathrm{RC}$ : relative change

Soil content of organic matter (\%) was increased significantly in the soil amended by compost and biochar application (Table, 2). The increases in this content associated with application of compost were higher than those found in the soil amended by biochar. These may be due the OM higher content of applied amendment added into the soil.

Applications of compost and biochar, significantly raised the soil CEC (cmole $\mathrm{Kg}^{-1}$ ) compared to that found in the untreated soil (Table, 2). These increases may be attributed to expand the soil surface area resulted from receiving organic amendment distinguished with higher specific surface area. The same results show that, the influence of compost on enhancing the CEC excelled that one of biochar, wherever the value of RC for the highest rate of applied compost showed an obvious effect more than double for that one of biochar.
Those results are in agreement with the results obtained by Helmi (2018).

\section{Soil content of available heavy metals}

Data presented in Tables (3 and 4) display the soil content $\left(\mathrm{mg} \mathrm{kg}^{-1}\right)$ of available heavy metals as affected by applications of compost and biochar. In general, the contents of available biogenic and non-biogenic heavy metals were increased with different applications of compost and biochar, where these increases were promoted with the incremental addition of organic amendments. Therefore, RC (\%) values of the soil available contents of heavy metals were positive. These increases may be attributed to the effect of the added amendments on soil properties especially decrease of soil $\mathrm{pH}$ and its content of $\mathrm{CaCO}_{3}$ as well as to the increases of soil CEC (Rabie, 2019). 
E.A. Abou Hussien, et al.,

At the same application rate of applied organic amendments, the content of available heavy metals in the soil amended by biochar was higher than that found with the compost treatment. This trend may be explained on the decomposition products of added organic amendments and its effect on soil chemical and biological properties. Also, this trend may be cleared from RC (\%) values of the soil content of available heavy metals, where at same application rate $\mathrm{RC}$, values in the soil amended by biochar showed efficiency more than that found with the treatment of compost. Similar results were observed partially by Rabie (2019).

At the same treatment of added organic amendments, data in Tables (3 and 4) exhibit wide variations in the available soil content $\left(\mathrm{mg} \mathrm{kg}^{-1}\right)$ of the determined heavy metals. These heavy metals could be arranged according to the means of the determined values affected by compost as follows: $\mathrm{Pb}>\mathrm{Fe}$
$>\mathrm{Mn}>\mathrm{Zn}>\mathrm{Co}>\mathrm{Ni}>\mathrm{Cu}>\mathrm{Cd}$. Same trend was also observed in the soil received biochar amendment. These results may be attributed to the initial soil content of both total and available heavy metals (Table, 1). The higher available $\mathrm{Pb}$ occurred in the experimented soil may be due to the traffic (cars) exhausts for long period. These findings are in concomitant with the data obtained by El Fouly and Tantawy (2016) and Mahmoud (2017). They found a positive relationship between the soil content of available heavy metals and the initial content of these metals as well as with the chemical composition of the used organic amendments and its application rate. It out to mention here in generally that application of both amendments augmented the available heavy metals more than double-fold with the highest rate of application, that refers to beneficial of that amendment in raising the value of the elements to be absorbed the remediated plant.

Table (3): Soil content of available of some biogenic heavy metals as affected by organic amendments applications $(O A)$

\begin{tabular}{|c|c|c|c|c|c|c|c|c|c|}
\hline \multicolumn{2}{|c|}{ Added OA } & \multicolumn{2}{|c|}{$\mathrm{Fe}$} & \multicolumn{2}{|c|}{ Mn } & \multicolumn{2}{|c|}{$\mathrm{Zn}$} & \multicolumn{2}{|c|}{$\mathrm{Cu}$} \\
\hline Source & Rate\% & $\mathrm{mg} \mathrm{kg}^{-1}$ & RC\% & $\mathrm{mg} \mathrm{kg}^{-1}$ & RC\% & $\mathrm{mg} \mathrm{kg}^{-1}$ & RC\% & $\mathrm{mg} \mathrm{kg}^{-1}$ & RC\% \\
\hline Control & 0.0 & 10.00 & & 8.25 & & 3.02 & & 0.68 & \\
\hline 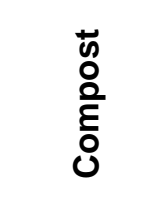 & $\begin{array}{c}0.5 \\
1.0 \\
2.0 \\
\text { Mean }\end{array}$ & $\begin{array}{l}10.55 \\
11.70 \\
13.50 \\
11.92\end{array}$ & $\begin{array}{c}5.50 \\
17.00 \\
35.00\end{array}$ & $\begin{array}{c}8.40 \\
9.15 \\
11.95 \\
9.83\end{array}$ & $\begin{array}{c}1.82 \\
10.91 \\
44.85\end{array}$ & $\begin{array}{l}3.10 \\
3.75 \\
8.82 \\
3.89\end{array}$ & $\begin{array}{c}2.65 \\
24.17 \\
59.60\end{array}$ & $\begin{array}{l}0.76 \\
0.82 \\
1.35 \\
0.98\end{array}$ & $\begin{array}{l}11.76 \\
20.59 \\
98.53\end{array}$ \\
\hline $\begin{array}{l}\frac{\overline{0}}{0} \\
\frac{0}{0} \\
\frac{0}{0}\end{array}$ & $\begin{array}{c}0.5 \\
1.0 \\
2.0 \\
\text { Mean }\end{array}$ & $\begin{array}{l}11.11 \\
12.95 \\
16.17 \\
13.41\end{array}$ & $\begin{array}{l}11.10 \\
29.50 \\
67.00\end{array}$ & $\begin{array}{c}9.03 \\
10.65 \\
14.33 \\
11.34\end{array}$ & $\begin{array}{c}9.70 \\
29.09 \\
73.70\end{array}$ & $\begin{array}{l}3.60 \\
4.62 \\
6.50 \\
4.91\end{array}$ & $\begin{array}{c}19.21 \\
52.98 \\
115.23\end{array}$ & $\begin{array}{l}0.80 \\
1.15 \\
2.05 \\
1.33\end{array}$ & $\begin{array}{c}17.65 \\
69.12 \\
201.47\end{array}$ \\
\hline L.SD at & $\begin{array}{l}a \\
b \\
a^{*} b\end{array}$ & $\begin{array}{l}0.1315 \\
0.1610 \\
0.2075\end{array}$ & & $\begin{array}{l}0.1107 \\
0.1356 \\
0.1748\end{array}$ & & $\begin{array}{l}0.0466 \\
0.0571 \\
0.0736\end{array}$ & & $\begin{array}{l}0.0127 \\
0.0156 \\
0.0201\end{array}$ & \\
\hline
\end{tabular}

$\mathrm{RC}$ : relative change 
Table (4): Soil available content ( $\mathrm{mg} \mathrm{kg}^{-1}$ ) of some non-biogenic heavy metals as affected by organic amendments applications $(O A)$.

\begin{tabular}{|c|c|c|c|c|c|c|c|c|c|}
\hline \multicolumn{2}{|c|}{ Added OM } & \multicolumn{2}{|c|}{ Co } & \multicolumn{2}{|c|}{ Cd } & \multicolumn{2}{|c|}{$\mathrm{Ni}$} & \multicolumn{2}{|c|}{$\mathrm{Pb}$} \\
\hline Source & Rate\% & $\mathrm{mg} \mathrm{kg}^{-1}$ & RC\% & $\mathrm{mg} \mathrm{kg}^{-1}$ & RC\% & $\mathrm{mg} \mathrm{kg}^{-1}$ & RC\% & $\mathrm{mg} \mathrm{kg}^{-1}$ & RC\% \\
\hline Control & 0.0 & 2.10 & & 0.07 & & 0.68 & & 15.02 & \\
\hline \multirow{4}{*}{ 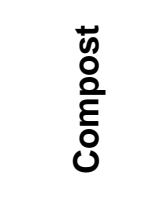 } & 0.5 & 2.25 & 7.14 & 0.07 & 0.00 & 0.72 & 5.88 & 15.90 & 5.86 \\
\hline & 1.0 & 2.90 & 38.10 & 0.09 & 28.57 & 0.98 & 44.12 & 17.25 & 14.85 \\
\hline & 2.0 & 4.10 & 95.24 & 0.18 & 157.14 & 1.65 & 142.65 & 31.30 & 41.81 \\
\hline & Mean & 3.08 & & 0.11 & & 1.12 & & 18.15 & \\
\hline \multirow{4}{*}{$\begin{array}{l}\frac{\pi}{0} \\
\frac{0}{0} \\
\frac{0}{0}\end{array}$} & 0.5 & 2.65 & 26.19 & 0.07 & 0.00 & 0.85 & 25.00 & 16.82 & 11.99 \\
\hline & 1.0 & 3.33 & 58.57 & 0.15 & 114.29 & 1.50 & 120.59 & 20.20 & 34.49 \\
\hline & 2.0 & 4.98 & 137.14 & 0.40 & 471.43 & 2.25 & 230.88 & 25.14 & 67.38 \\
\hline & Mean & 3.65 & & 0.21 & & 1.53 & & 20.72 & \\
\hline \multirow[t]{3}{*}{ L.SD at0. } & $\mathbf{a}$ & 0.0359 & & 0.0020 & & 0.0147 & & 0.2023 & \\
\hline & b & 0.0439 & & 0.0025 & & 0.0180 & & 0.2477 & \\
\hline & $a^{*} b$ & 0.0566 & & 0.0032 & & 0.0232 & & 0.3193 & \\
\hline
\end{tabular}

$\mathrm{RC}$ : relative change

Fresh and dry matter yield of sugar beet plants

Data in Table (5) exhibit the fresh and dry weights (g/pot) of both roots and shoot of sugar beet plants grown on the experimental soil as a result of two organic amendments applications at different rates. Different applications of compost and biochar significantly increase the fresh and dry matter yields of sugar beet plants (roots and shoots). The highest weights $\left(\mathrm{g} \mathrm{pot}^{-1}\right)$ as well as its RC (\%) were observed with the high rate (2\%) of the tested organic amendments. These results are in correspondence with Elgezery (2016) and Hammad (2019), who mentioned that, application of organic amendments into different soils of Egypt resulted in a significant increase of many plant growth and productivity. This may be ascribed to that the enhancing effect of organic amendments on plant growth in due its effect on soil fertility especially its content of available macro and micronutrients. The obtained results denoted that the influence of compost addition on promoting plant growth excelled that of biochar one (Table, 5). These findings may be attributed to the chemical composition of the two organic amendments (Table, 1) and its effect on soil properties (Table, 2). El-Khamisy (2017) and Hessen (2019) reported similar results in agreement with the obtained results.

\section{Sugar beet plants content of heavy metals}

Data in Tables (6 and 7) appeared that, increasing rate of added compost and biochar significantly increased the determined heavy metals ( $\mathrm{Mn}, \mathrm{Zn}, \mathrm{Cu}, \mathrm{Co}$, $\mathrm{Cd}, \mathrm{Ni}$ and $\mathrm{Pb}$ ) content of roots and shoots of sugar beet plants. The rate of these increased may be cleared from RC (\%) values wherever, the incremental of the addition of amendments ascending the augmented of the plant content from the determined heavy metals. The highest of application percent magnified that content by more than $50 \%$ compared 
E.A. Abou Hussien, et al.,

to the control. These results are in concordance with those obtained by Heba (2003) and Mahmoud (2017).

At the same application rate of organic amendments data in Tables (6 and 7) show that, heavy metals determined values in the plants grown on the soil amended by compost were higher than that one received biochar. This trend was in similar with both roots and shoots. The superior increase effect of compost applications on $\mathrm{Cu}$ and $\mathrm{Zn}$ uptake by sunflower plants compared with that associated the treatment of biochar pointed by Mahmoud (2017).

Regarding the distribution of the high absorbed heavy metals within roots and shoots of sugar beet plants grown on the polluted soil, data in Tables (6 and 7) show a high shoots uptake of the determined heavy metals compared with those absorbed by roots at the same treatments of the tested organic amendments. They may be imputed to the higher fresh weights of shoots than that of roots by more than double fold (Table, 5). These results means that, sugar beet plants may be used as a good plant to remediation for the heavy metals from the polluted soils especially this accumulation occurred mainly in the shoots.

Sugar beet (roots or shoots) plants content $\left(\mathrm{mg} \mathrm{plant}^{-1}\right)$ of the determined heavy metals at the same treatment of soil organic amendments varied widely from metal to another depending on the initial content of each metal in the soil as well as solubility affected by the soil treatments. The highest uptake was found with $\mathrm{Pb}$ followed by $\mathrm{Fe}$, but the lowest one was found with Cd. Nearly this trend was found with roots and shoots with different treatments of organic amendments.

Table (5): Fresh and dry weights (g pot ${ }^{-1}$ ) of sugar beet plants (shoots and roots) grown on the studied soil as affected by organic amendments applications (OA).

\begin{tabular}{|c|c|c|c|c|c|c|c|c|c|}
\hline \multicolumn{2}{|c|}{ Added (OA) } & \multicolumn{4}{|c|}{ Fresh weights } & \multicolumn{4}{|c|}{ Dry weights } \\
\hline \multirow{2}{*}{ Source } & \multirow{2}{*}{$\begin{array}{l}\text { Rate } \\
\text { (\%) }\end{array}$} & \multicolumn{2}{|c|}{ Roots } & \multicolumn{2}{|c|}{ Shoots } & \multicolumn{2}{|c|}{ Roots } & \multicolumn{2}{|c|}{ Shoots } \\
\hline & & g pot $^{-1}$ & RC\% & g pot pot $^{-1}$ & RC\% & g pot ${ }^{-1}$ & RC\% & g pot ${ }^{-1}$ & RC\% \\
\hline Control & 0.0 & 90.10 & & 205.50 & & 26.25 & & 56.90 & \\
\hline 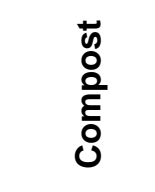 & $\begin{array}{c}0.5 \\
1.0 \\
2.0 \\
\text { Mean }\end{array}$ & $\begin{array}{l}107.10 \\
120.15 \\
133.30 \\
120.18\end{array}$ & $\begin{array}{l}18.87 \\
33.53 \\
47.59\end{array}$ & $\begin{array}{l}230.30 \\
260.50 \\
296.16 \\
262.32\end{array}$ & $\begin{array}{l}12.07 \\
26.76 \\
44.12\end{array}$ & $\begin{array}{l}30.90 \\
35.15 \\
39.11 \\
35.05\end{array}$ & $\begin{array}{l}18.52 \\
33.90 \\
48.99\end{array}$ & $\begin{array}{l}62.13 \\
68.75 \\
76.13 \\
69.00\end{array}$ & $\begin{array}{c}9.19 \\
20.83 \\
33.80\end{array}$ \\
\hline $\begin{array}{l}\frac{\pi}{0} \\
\frac{\pi}{0} \\
\frac{0}{0}\end{array}$ & $\begin{array}{c}0.5 \\
1.0 \\
2.0 \\
\text { Mean }\end{array}$ & $\begin{array}{c}98.15 \\
113.00 \\
120.20 \\
110.45\end{array}$ & $\begin{array}{c}8.93 \\
25.42 \\
33.45\end{array}$ & $\begin{array}{l}215.25 \\
233.33 \\
268.70 \\
239.59\end{array}$ & $\begin{array}{c}4.95 \\
13.57 \\
31.01\end{array}$ & $\begin{array}{l}28.50 \\
33.11 \\
33.60 \\
32.25\end{array}$ & $\begin{array}{c}6.86 \\
26.13 \\
35.62\end{array}$ & $\begin{array}{l}59.80 \\
63.60 \\
70.75 \\
64.72\end{array}$ & $\begin{array}{c}5.10 \\
11.78 \\
24.34\end{array}$ \\
\hline L.S.D at & $\begin{array}{l}05 \\
\mathbf{a} \\
\mathbf{b} \\
\mathbf{a}^{*} \mathbf{b}\end{array}$ & $\begin{array}{l}1.190 \\
1.457 \\
1.878\end{array}$ & & $\begin{array}{l}2.590 \\
3.172 \\
4.089\end{array}$ & & $\begin{array}{l}0.345 \\
0.422 \\
0.544\end{array}$ & & $\begin{array}{c}0.689 \\
0.844 \\
1.88\end{array}$ & \\
\hline
\end{tabular}

$\mathrm{RC}$ : relative change 


\begin{tabular}{|c|c|c|c|c|c|c|}
\hline \multirow{4}{*}{ త } & \multirow{2}{*}{ 苋 } & ఝ ఏ & & 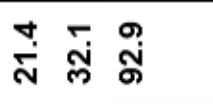 & 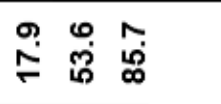 & \\
\hline & & 물 & $\stackrel{\infty}{N}$ & 岀 & 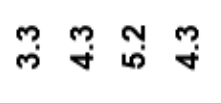 & 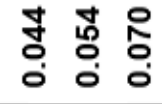 \\
\hline & \multirow{2}{*}{$\begin{array}{l}\frac{n}{0} \\
\frac{2}{\infty}\end{array}$} & Uః & & 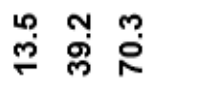 & 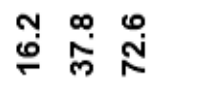 & \\
\hline & & 要。 & $\stackrel{+}{N}$ & 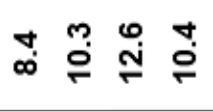 & 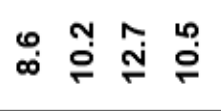 & 흥 \\
\hline \multirow{4}{*}{ N } & \multirow{2}{*}{ 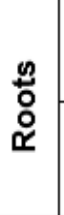 } & U ఏ & & 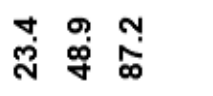 & 읻 & \\
\hline & & 害。 & $\stackrel{r}{\dot{\gamma}}$ & $\underset{\omega}{\infty} \stackrel{\infty}{\Gamma} \underset{\infty}{\infty} \underset{\infty}{\infty}$ & $\begin{array}{llll}0 & 9 & 0 & \infty \\
0 & 0 & \infty & 0 \\
\omega\end{array}$ & 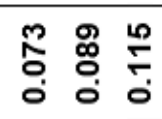 \\
\hline & \multirow{2}{*}{$\begin{array}{l}\frac{0}{0} \\
\frac{2}{\omega}\end{array}$} & u ఏ & & 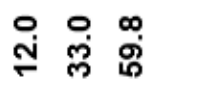 & 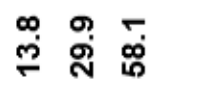 & \\
\hline & & 밀 & $\stackrel{T}{=}$ & 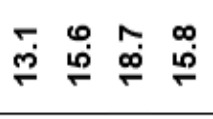 & 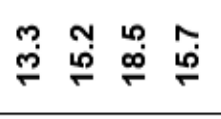 & 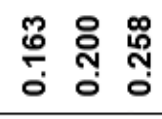 \\
\hline \multirow{4}{*}{$\frac{\Sigma}{\Sigma}$} & \multirow{2}{*}{ 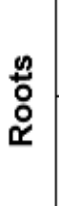 } & ¿ す & & 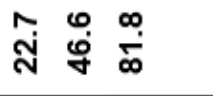 & 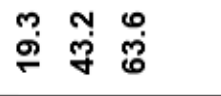 & \\
\hline & & 물 & $\underset{\infty}{\infty}$ & 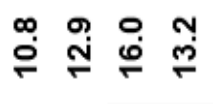 & 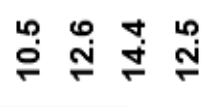 & 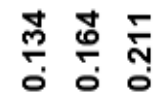 \\
\hline & \multirow{2}{*}{$\begin{array}{l}\frac{n}{\circ} \\
\frac{2}{\infty}\end{array}$} & ఝ ఏ & & $\stackrel{g}{=} \stackrel{0}{=} \stackrel{0}{\text { : }}$ & 울 ஸ्் & \\
\hline & & 욜 & $\hat{\mathfrak{N}}$ & 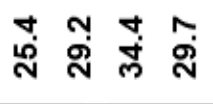 & స్ & 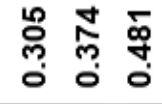 \\
\hline \multirow{4}{*}{ ํㅜㄴ } & \multirow{2}{*}{ 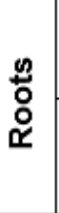 } & ఝ @ & & స்̃ & 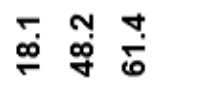 & \\
\hline & & 뭄 & $\underset{\infty}{\infty}$ & 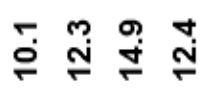 & 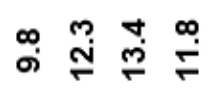 & 온 \\
\hline & \multirow{2}{*}{$\begin{array}{l}\frac{n}{2} \\
\stackrel{2}{\infty}\end{array}$} & U ఏ & & 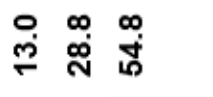 & 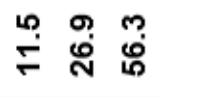 & \\
\hline & & 苗 & 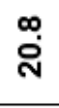 & 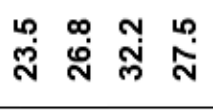 & 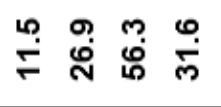 & 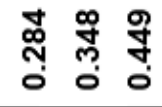 \\
\hline \multirow{2}{*}{ 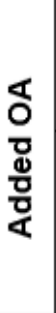 } & & ֻँّ & $\because$ & 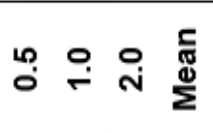 & 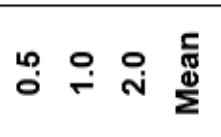 & $\pi$ ค \\
\hline & & : & Do & Isoduos & дечગо!ด & 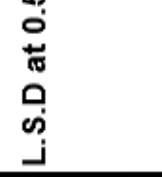 \\
\hline
\end{tabular}


E.A. Abou Hussien, et al.,

\begin{tabular}{|c|c|c|c|c|c|c|c|c|c|c|}
\hline \multirow{4}{*}{$\frac{0}{\alpha}$} & \multirow{2}{*}{ 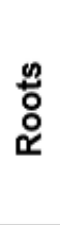 } & Uః & & స & $\begin{array}{l}\infty \\
\infty \\
\infty\end{array}$ & & 웅 웅 & & & \multirow[b]{2}{*}{ 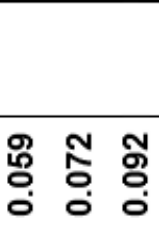 } \\
\hline & & 욜 & స̃ & 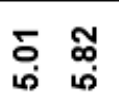 & $\stackrel{R}{6}$ & 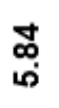 & $\begin{array}{ll}\stackrel{0}{0} \\
\stackrel{0}{0}\end{array}$ & শ্் & & \\
\hline & \multirow{2}{*}{$\begin{array}{l}\frac{0}{\circ} \\
\frac{2}{5}\end{array}$} & U ‡ & & $\stackrel{\circ}{\circ}$ & $\overline{5}$ & & 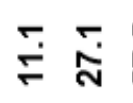 & مُ & & \\
\hline & & 뮬 & $\stackrel{\cong}{\check{F}}$ & 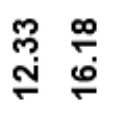 & $\stackrel{\delta}{\stackrel{\delta}{\digamma}}$ & ڤે & 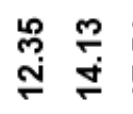 & $\stackrel{\Sigma}{\stackrel{50}{\sigma}}$ & & 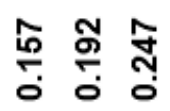 \\
\hline \multirow{4}{*}{$\overline{\mathbf{z}}$} & \multirow{2}{*}{ 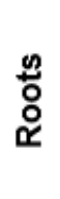 } & U ఏ & & 옹 巳্் & $\bar{s}$ & & 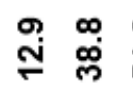 & $\sum_{i}^{\infty}$ & & \\
\hline & & 뭍ㅁํㅁ & $\stackrel{\mathscr{\infty}}{0}$ & $\stackrel{\text { ণ }}{\leftarrow}$ & $\stackrel{\text { Y }}{\leftarrow}$ & సุ & $\stackrel{\circ}{\stackrel{\circ}{\leftarrow}}$ & $\stackrel{\text { શి }}{\leftarrow}$ & & 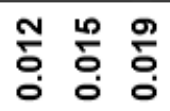 \\
\hline & \multirow{2}{*}{$\begin{array}{l}\frac{2}{0} \\
\frac{1}{\omega}\end{array}$} & U ఏ & & $\stackrel{+}{\stackrel{5}{*}}$ & $\stackrel{m}{\dot{m}}$ & & $\begin{array}{ll}\infty \\
\infty \\
\infty\end{array}$ & $\bar{g}$ & & \\
\hline & & 뮬 & స̃ & \begin{tabular}{ll}
\multirow{H}{*}{} & సั \\
N่
\end{tabular} & 年 & ลิ & 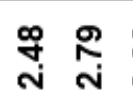 & m & 心్ & ⿸厃㔾 \\
\hline \multirow{4}{*}{ J } & \multirow{2}{*}{ 号 } & U ఏ & & 苞 ᄋ̊ & $\stackrel{N}{N}$ & & மீ & $\underset{\infty}{\infty}$ & & \\
\hline & & 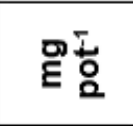 & $\stackrel{5}{5}$ & 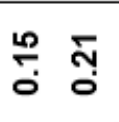 & & సุ & $\stackrel{\circ}{\check{0}}$ & s. & ฺָָ & 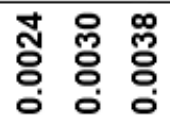 \\
\hline & \multirow{2}{*}{$\begin{array}{l}\stackrel{2}{\circ} \\
\text { ๖ }\end{array}$} & บ ‡ & & 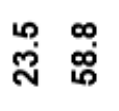 & $\stackrel{\infty}{\stackrel{\infty}{\rightleftarrows}}$ & & స્లે & ঙ্লָ & & \\
\hline & & 모ㄹㅠㅛ & लै. & フ̛ & 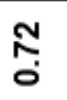 & 萬 & 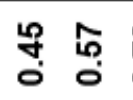 & & ๑̊: & 옹 웅 응 \\
\hline \multirow{4}{*}{ ن } & \multirow{2}{*}{ 号 } & U ఏ & & ஒே & ஷุ่ & & $\stackrel{ \pm}{=}$ ஸ् & $\begin{array}{l}\infty \\
\dot{J}\end{array}$ & & \\
\hline & & 율뮴 & $\stackrel{2}{\circ}$ & $\stackrel{\text { ஸ̣ }}{\sim}$ & $\stackrel{\Gamma}{r}$ & 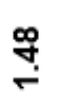 & 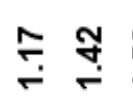 & $\stackrel{\text { ઼ָ }}{\leftarrow}$ & $\stackrel{n}{\circ}$ & 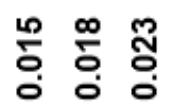 \\
\hline & \multirow{2}{*}{$\begin{array}{l}\stackrel{8}{\circ} \\
\text { क }\end{array}$} & U ‡ & & $\stackrel{\oplus}{\stackrel{0}{\circ}}$ & กิ่ & & 울 움 & กิ่ & & \\
\hline & & 욜 & 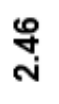 & 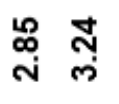 & 营 & $\bar{m}$ & $\stackrel{\infty}{\stackrel{\infty}{N}} \underset{\text { i }}{\stackrel{0}{r}}$ & g. & ণ্ণ & 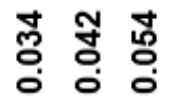 \\
\hline \multirow{2}{*}{$\begin{array}{l}\varangle \\
\text { O } \\
\text { d } \\
\frac{\mathrm{d}}{0} \\
\frac{0}{0}\end{array}$} & & ֻั & 웅 & $\stackrel{\circ}{\circ} \stackrel{0}{\circ}$ & $\stackrel{\text { ì }}{ }$ & 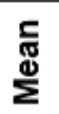 & $\stackrel{0}{\circ} \stackrel{0}{\leftarrow}$ & $\stackrel{\circ}{\text { ì }}$ & 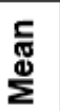 & \multirow{2}{*}{ 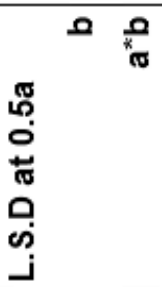 } \\
\hline & & 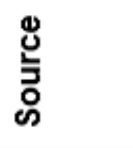 & 혼 & jsodu & щоว & & децә & & & \\
\hline
\end{tabular}




\section{CONCLUSIONS}

Data of this study concluded the high importance and beneficial effects of organic amendments such as compost and biochar on enhancing the uptake of the determined heavy metals. This tremendous uptake by plants shoots and roots may be taking the consideration the importance of sugar beet plants in removing heavy metals from the soil, consequently it may be considered as a phytoremediated of the contaminated soils.

\section{REFERENCES}

Abd El-Aal, M. H. Khalifa D. M. and M. I. M. Abdalla (2018). Impacts of different rates of compost, proline-spray and irrigation on some soil properties and sudan grass grown in saline soil. Menoufia J. Soil Sci., 3 (December) 267- 281.

Abou Hussien, E., A. M. Elbaalawy and M. Hammad (2019). Chemical properties of compost in relation to calcareous soil properties and its productivity of wheat. Egyptian Journal of Soil Science, 59(1): 85-97.

Basiouny, A.G.A. (2016). Environmental evaluation of water quality in some open drains in North Africa and its effect on soil and plants. M.Sc. Thesis, Inst. of African Res., Cairo Univ., Egypt.

Chen. M., P. Xu., G. Zeng., C. Yang, D. Huang and J. Zhang (2015). Bioremediation of soils contaminated with polycyclic aromatic hydrocarbons, petroleum, pesticides, chlorophenols and heavy metals by composting: applications, microbes and future research needs. Biotechnology advances, 33(6): 745755.

CoStat., V. (2005). Cohort Software798 light house Ave. PMB320, Monterey, CA93940, and USA. Email: info@cohort.com and Website: http://www.cohort.com. Download Co Stat Part2.html.
Cottenie, A., M. Verloo, L. Kickens, G. Velghe and R. Camerlynck (1982). Chemical analysis of plants and soils. Laboratory of Analytical and Agro chemistry, State University, Ghent Belgium, pp.: 63.

de Varennes, A., M. J. Goss and $M$. Mourato (2006). Remediation of a sandy soil contaminated with cadmium, nickel, and zinc using an insoluble polyacrylate polymer. Communications in Soil Science and Plant Analysis, 37(11-12): 1639-1649.

Downie, A., A. Crosky and P. Munroe (2012). Physical properties of biochar. Biochar for Environmental Management (pp. 45-64). Rutledge.

El Fouly, A.S. and M.F. Tantawy (2016). Use of Irradiated Ornamental Plant (Sunflower) and Soil Amendments for Heavy Metals Removing from Polluted Soil. Middle East Journal of Applied Sciences, 6(1): 139-154.

Elgezery, M. K. (2016). Effect of organic additives on efficiency of sulphur fertilization. M. Sc. Thesis, Fac. of Agric., Menoufia Univ., Egypt.

El-Gamal, B. A. H. (2015). Effect of some soil amendments on soil conditions and plant growth. Ph.D. Thesis, Fac. of Agric., Menoufia Univ., Egypt.

El-Khamisy, R.R.A. (2017). Effect of different soil amendments with fertilizer application on some soil properties and maize growth in clay soil. Ph. Thesis, Fac., of Agric., Tanta Univ., Egypt.

Faiyad, R.M.N. (2014). Bioremediation of chemically polluted soils and effect on plant growth. Ph.D. Thesis, Fac. of Agric., Menoufia Univ., Egypt.

Gaskin, J. W., C. Steiner, K. Harris, K. C. Das and B. Bibens (2008). Effect of low-temperature pyrolysis conditions on biochar for agricultural use. Transactions of the ASABE, 51(6): 2061-2069.

Gibbs, P. A., B. J. Chambers, A. M. Chaudri, S. P. McGrath and C. H. 
Carlton-Smith (2006). Initial results from long-term field studies at three sites on the effects of heavy metal-amended liquid sludge on soil microbial activity. Soil Use and Management, 22(2): 180-187.

Glaser, B. (2007). Prehistorically modified soils of central Amazonia: a model for sustainable agriculture in the twentyfirst century. Philosophical Transactions of the Royal Society B: Biological Sciences, 362(1478): 187196.

Hammad, M.A.B. (2019). Combined effect of organic and mineral fertilization on nodulation and yield of common bean (Phaseolusvulagaris L.) under sandy soil conditions. M.Sc. Thesis, Fac. of Agri. Menoufia Univ. Egypt.

Heba, M. I. A (2003). Remediation of some heavy metal polluted soils in Nile Delta Egypt. M.Sc. Thesis, Fac. Agric., Tanta Univ., Egypt.

Helmi, M. Y. (2018). Impact of Using Some Chemical and Biological Treatments on Ameliorating Salt Affected Soil and Its Productivity. Ph. D. Thesis, Fac. of Agric., Benha Univ., Egypt.

Hessen, A. M. A. (2019). Effect of gamma rays on properties of Leucaena Leucocephala compost under field conditions. M. Sc. Thesis, Fac. of Agric., Menoufia Univ., Egypt.

Klute, A. and C. Dirksen (1986). Hydraulic conductivity and diffusivity. In Klute, A. (Ed.) Methods of soil analysis. Part (I) Physical and mineralogical methods, 2nd ed. Agron. Monogr. 9. ASA-SSA, Madison, WI, PA. 687- 734.

Krull, E. S., J. A. Baldock, J. O. Skjemstad and R. J. Smernik (2012). Characteristics of biochar: organochemical properties. Biochar for Environmental Management (pp. 8598). Rutledge.

Laird, D. A., R. C. Brown, J. E. Amonette and J. Lehmann (2009). Review of the pyrolysis platform for coproducing bio-oil and biochar. Biofuels, Bio products and Bio refining, 3(5): 547562.

Lehmann, J. (2007b). A handful of carbon. Nature, 447(7141): 143-144.

Lehmann, J. and S. Joseph (2009). Biochar for Environmental Management: Science and Technology; Earth scan: London and Sterling, VA.

Mahmoud, H.M.A. (2017). Organic amendments and their effect on status of some nutrients in soil and plant Ph. D. Thesis, Fac. of Agric., Menoufia Univ., Egypt.

Page, A. L., R. H. Miller and D. Ft. Keeney (1982). "Methods of Soil Analysis" Part 2. Chemical and Microbiological properties second Edition. Wisconsin, U.S.A.

Perez-Piqueres, A., V. Edel-Hermann, C. Alabouvette and C. Steinberg (2006). Response of soil microbial communities to compost amendments. Soil Biology and Biochemistry, 38(3): 460-470.

Rabie, S.T.M. (2019). Evaluation the agriculture environment quality in the contaminated and manured soils in North Africa. M.Sc. Thesis, Fac. of African Postgraduate Studies, Cairo Univ., Egypt.

Tantawy, M. F. (2004). Monitoring of environmental pollution with heavy metals in some Delta soils and its phyto remediation. Ph. D. Thesis, Fac. of Agric., Kafr El-Sheikh, Tanta Univ., Egypt.

Walker, D.J., Clemente, R. R. A. and Bernal, M.P. (2003): The effects of soil amendments on heavy metal bioavailability in two contaminated Mediterranean soils. Environ. Poll.122: 303-312.

Wang, N., J. Y. Li and R. K. Xu (2009). Use of agricultural by-products to study the $\mathrm{pH}$ effects in an acid tea garden soil. Soil Use and Management, 25(2): 128-132. 
استخدام سماد المكمورة والفحم الحيوي في زيادة المعالجة النباتية للتربة الملوثة

الحسيني عبد الففار أبو حسين، محمد محمد حمادة شلبي، بخيت سعيد عمر الثحري

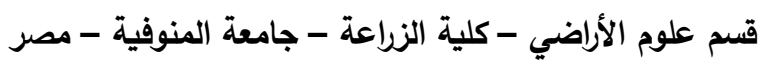

الملخص العربي

أجريت تجربة أصص لمعالجة الملوثات الناتجة عن تراكم العناصر الثقيلة في التربة بمنطقة بركة السبع - محافظة

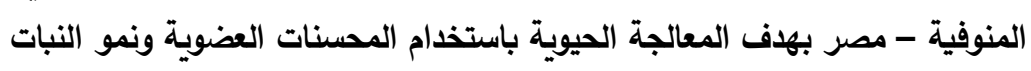

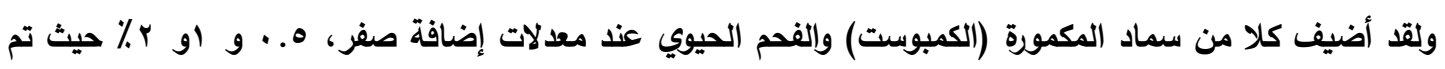

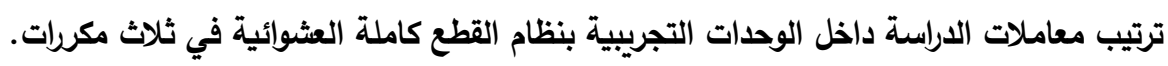

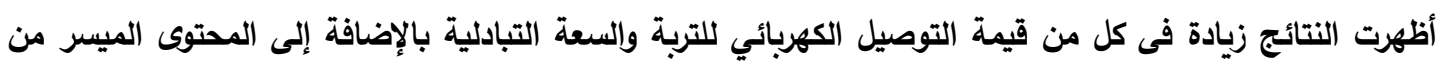

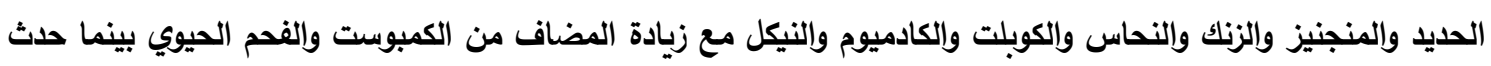

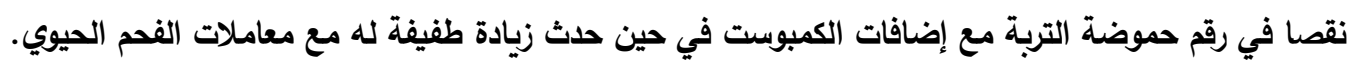

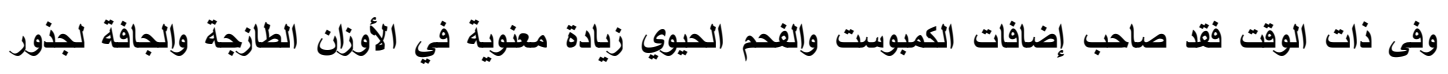

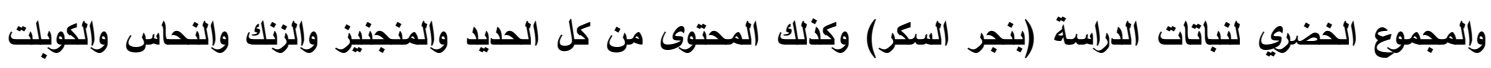
والكادميوم. و قد أظهرت النتائج أهمية نبات بنجر السكر في امتصاص العناصر الثقيلة من التربة، وبالتالي يكن اعتباره معالج نباتي للتلوث بالعناصر الثقيلة. 